\title{
O caráter problemático de Paulo Honório
}

\author{
The problematic feature of Paulo Honório
}

Raul Azevedo de Andrade FERREIRA*

Universidade Regional do Cariri (URCA)

RESUMO: O presente artigo revisita uma tradição interpretativa do romance São Bernardo, de Graciliano Ramos, apoiada na categoria de herói problemático, lançada por Georg Lukács em sua Teoria do Romance (1914). Argumenta-se que as leituras produzidas por críticos como Lafetá (1984) e Abdala Júnior (2007) apoiam-se em uma leitura enviesada dos conceitos do filósofo húngaro e que, por conta disso, podem ser reconsideradas. Por fim, o texto retoma a tipologia do herói romanesco lançada por Lukács e propõe uma interpretação do romance do autor alagoano na qual seu protagonista passa a ser entendido como um idealista quixotesco.

PALAVRAS-CHAVE: São Bernardo. Graciliano Ramos. Teoria do Romance.

ABSTRACT: This article revisits an interpretative tradition of the novel São Bernardo, by Graciliano Ramos, based on the problematic hero category launched by Georg Lukács in his Theory of the Novel (1914). It is argued that the interpretations produced by critics such as Lafetá (1984) and Abdala Júnior (2007) rest on a biased reading of the concepts of the Hungarian philosopher and, because of that, can be reconsidered. Finally, the text considers the novelistic hero typology launched by Lukács and proposes a new interpretation of the novel written by the alagoano author in which its protagonist is understood as a quixotic idealist.

KEYWORDS: São Bernardo. Graciliano Ramos. Theory of the Novel.

Recebido em 3 de outubro de 2016. Aprovado em 22 de novembro de 2016.

\footnotetext{
* Doutor em Teoria da Literatura pelo Programa de Pós-Graduação em Letras da Universidade Federal de Pernambuco (PPGL - UFPE), professor do Departamento de Línguas e Literaturas da Universidade Regional do Cariri (URCA). E-mail para contato: raulandradef@ hotmail.com.
} 


\section{Introdução}

Quando Georg Lukács, em A teoria do Romance (2000), analisa o surgimento do romance a partir da grande épica, a personagem romanesca é tomada como o principal elemento caracterizador do gênero. Segundo Lukács, a transformação do herói comunitário das antigas epopeias em um indivíduo dotado de um caráter problemático marca o momento formal em que um gênero desaparece e outro toma o seu lugar. Apesar de várias implicações da teoria de Lukács ainda merecerem uma revisão cuidadosa - como o modo como as transformações da série literária ligam-se às transformações sociais ou mesmo se é possível dizer que a poesia épica realmente desapareceu - suas ideias se mantêm relevantes para a reflexão de uma série de aspectos do romance, mesmo daqueles produzidos anos depois de Lukács ter redigido seu livro em 1914.

Para a literatura brasileira, a ideia do protagonista romanesco ser caracterizado como um herói problemático parece ter se casado com uma interessante leitura de São Bernardo, romance de Graciliano Ramos. A história de um sertanejo determinado a enriquecer através de seu suor e da exploração do trabalho de outros homens encaixouse com um entendimento do caráter problemático do indivíduo romanesco, sobretudo se esse entendimento for mediado por uma terminologia da teoria marxista, como acontece na Sociologia do romance (1990) de Lucien Goldmann. Este ensaio pretende analisar as relações das ideias de Lukács com outras ideias afins, sobretudo as de Walter Benjamin e Adorno. Em seguida, ele comentará algumas leituras de São Bernardo realizadas a partir do conceito de herói problemático a fim de argumentar como implicam uma consideração parcial das ideias apresentadas por Lukács, sobretudo quando se trata de sua tipologia da forma romanesca. Por fim, ele proporá uma leitura ainda não tentada do romance a partir do conceito de herói problemático.

\section{Os mundos épico e romanesco}

Segundo Lukács (2000, p. 36), o romance possui a mesma intenção artística da grande épica, porém o mundo que viu surgir as antigas epopeias desapareceu completamente, de maneira que esta intenção teve que ser atualizada a partir de um novo gênero literário. Isto ocorre porque, segundo Lukács, os gêneros literários estão submetidos a uma dialética tanto filosófica quanto histórica, o que significa que uma 
mesma intenção épica torna-se responsável por diferentes formas literárias ao ser condicionada por diferentes conjunturas sociais, especialmente no que tange as diferentes orientações transcendentais que cada comunidade é capaz de oferecer aos seus participantes. O nascimento e desaparecimento dos gêneros, portanto, são determinados pelas transformações ocorridas no plano histórico. Segundo tal linha de raciocínio, o entendimento do romance e de seu surgimento depende sobretudo da análise das condições epistemológicas fornecidas pela sociedade, isto é: em como uma dada conjuntura histórica entende a essência das coisas e dos atos como algo possível.

A grande épica é então apresentada como um gênero artístico correspondente à mentalidade encontrada nas comunidades fechadas do mundo grego. Segundo Lukács (2000, p. 30), tais comunidades teriam vivido em um círculo metafísico bastante estreito, o que possibilitava uma orientação transcendental não problemática. Tal orientação significa que, para o mundo da grande épica, as essências - os sentidos dos atos, das coisas e dos homens - são vivenciadas enquanto substâncias imanentes; cada ato e cada coisa traria em si o sentido que eles portam. Além disso, as essências seriam estáveis e comuns, compartilhadas por todos pertencentes à comunidade, de modo que não somente a relação dos homens com as coisas não é problemática, mas também a própria relação dos homens entre eles próprios é vivenciada como algo espontâneo: “É um mundo homogêneo, e tampouco a separação entre homem e mundo, entre eu e tu é capaz de perturbar essa homogeneidade" (LUKÁCS, 2000, p. 29). É por isso que essa mentalidade é apresentada como sendo algo anterior à reflexão filosófica, pois a reflexão já sinaliza uma diluição da substância das essências.

A análise do mundo épico realizada por Lukács possui alguns pontos em comum com a apresentação que Walter Benjamin faz do mundo das narrativas populares. Benjamin (1994, p. 55) entende a narrativa como a representante em prosa da pureza do espírito épico; ela seria uma modalidade do gênero épico ao lado da epopeia e da crônica histórica, de maneira que tais modalidades compartilhariam o mesmo mundo e destino tão logo ocorra o desaparecimento desse mundo. Benjamin, entretanto, não reflete a partir da noção de orientação transcendental, mas pela ideia de mundo ético. Segundo ele, em seu célebre ensaio sobre o narrador (BENJAMIN, 1994), o mundo das formas épicas comporta uma sociedade onde as pessoas encontram-se integradas umas às outras a partir de experiências comuns e intercambiáveis. Pode-se dizer que a 
narrativa, assim como as demais modalidades do gênero épico, é capaz de portar a sabedoria contida em cada ação da experiência porque o sentido das ações e das coisas ainda permanece imanente e estável, e tal imanência simultaneamente possibilita e é assegurada pela homogeneidade da comunidade. Adorno (2003, p. 56) fala da "identidade da experiência, a vida articulada e em si mesma contínua, que só a postura do narrador permite". Assim, a narrativa - diferentemente do romance - é um gênero em que o sentido da vida ainda não é vivenciado como algo problemático, sua dimensão pragmática encontra-se não na investigação do destino de um indivíduo isolado, mas no ensinamento aplicável a cada um dos homens através de uma "moral da história". A ideia de uma "moral da história", de um ensinamento cuja validade transcende quaisquer particularidades individuais, implica um mundo ético dotado da mesma orientação transcendental apresentada por Lukács como sendo a das comunidades fechadas do mundo épico.

Como já foi dito acima, esta orientação transcendental responsável pela manutenção da imanência e substancialidade das essências somente foi possível devido à dimensão estreita do círculo metafísico das comunidades fechadas - algo que Benjamin de certa forma apresenta a partir da imagem de um modo de vida agrário e artesanal. Esta unidade metafísica assegura a totalidade de cada coisa antes mesmo que o homem sinta a necessidade de produzir novas totalidades através da formalização do mundo. Assim sendo, a própria totalidade do indivíduo é desenhada a partir de uma essência que já se encontra pré-fabricada em tal unidade, de modo que o indivíduo carece de uma consciência de si como um ente separado das coisas e dos outros homens. Daí Lukács (2000, p. 67) poder afirmar que "o herói da epopeia nunca é, a rigor, um indivíduo"; Bakthin expressa uma ideia semelhante:

Ele [o homem dos gêneros épicos] é inteiramente perfeito e terminado. Ele é concluído num alto nível heroico, mas está desesperadoramente pronto, ele está todo ali, do começo ao fim, ele coincide consigo próprio e é igual a si mesmo. Ademais, ele é completamente exteriorizado. Entre sua verdadeira essência e o seu aspecto exterior não há a menor discrepância. (1998, p. 423)

Este acabamento e carência de individualização implica o homem estreitado na mesma medida do círculo em que ele habita: homem e mundo possuem o mesmo tamanho. Tal como acontece com o homem, a organicidade do mundo épico assegura 
uma totalidade acabada também às formas artísticas. Assim como o indivíduo é formado antes que lhe seja possível destacar-se do todo através de um individualismo, a arte também encontra-se acabada antes que o espírito se incuba da tarefa de produzi-la. Lukács apresenta as formas da grande épica como um produto cuja totalidade não é artisticamente elaborada, mas antes copiada das totalidades fornecidas pela unidade do mundo. Benjamin apresenta esse caráter da épica através da ligação telúrica do narrador. Segundo ele (BENJAMIN, 1994, p. 201), há narrativa quando o relato alimenta e é alimentado pela tradição oral, pois, da mesma forma que cada indivíduo, o relato épico não se encontra deslocado do todo da comunidade, ele se produz assim como todas as demais essências do mundo: espontaneamente. Benjamin (1994, p. 54) apresenta a espontaneidade das formas épicas através da imagem do homem que deita na praia e apenas escuta as ondas, que se limita a repousar, e nesse seu repouso todo o povo repousa depois de um dia de trabalho, ao passo que o romancista seria aquele que se isola e decide realizar uma travessia marítima: "o romancista se separou de seu povo e do que ele faz. A matriz do romance é o indivíduo em solidão” (BENJAMIN, 1994, p. $54)$.

Já o romance é o gênero literário característico de uma sociedade destituída do fechamento que Lukács apresenta como sendo o da grande épica. Nos textos de Benjamin, Adorno e Goldmann essa sociedade surge como sendo a produzida pelo capitalismo industrial. Nela a arte abandona o contexto homogêneo proporcionado pelas antigas sociedades agrárias e passa a se relacionar com as convenções da ideologia burguesa. Lukács, entretanto, prefere focar seu argumento em categorias filosóficas e metafísicas. Segundo sua caracterização, o mundo do romance é um mundo abandonado pelos deuses, consequentemente as coisas e os atos perderam a substancialidade do Ser. Desamparado, o homem também já não pode mais estar integrado ao Cosmo e ao todo de sua comunidade, os homens se separaram e o sentido das coisas não são mais evidentes, deve ser procurado solitariamente na travessia marítima mencionada por Benjamin. Essa busca individual é desenvolvida através da formalização da vida, que se constitui como uma tentativa vã de construir um sentido que apreenda o Ser, a essência das coisas:

A composição do romance é uma fusão paradoxal de componentes heterogêneos e descontínuos numa organicidade constantemente revogada. As relações que mantêm a coesão dos componentes 
abstratos são, em sua pureza abstrata, formais: eis porque o princípio unificador último tem de ser a ética da subjetividade criadora que se torna nítida no seu conteúdo (LUKÁCS, 2000, p. 85).

O romance é o produto de uma mentalidade formalizadora, configuradora (LUKÁCS, 2000, p. 30); Benjamin (1994, p. 56) aponta a montagem como sendo o princípio estilístico das narrativas burguesas. Na teoria de Lukács, entretanto, essa atitude, derivada do que ele chama de "produtividade do espírito" (LUKÁCS, 2000, p. 30), não se restringe ao romance ou à literatura, mas encontra-se presente nos diversos idealismos criados para mediar o contato com a realidade. Se antes os deuses sustentavam as relações transcendentais que asseguravam a essencialidade da vida, o homem não possuía espaço para a inventividade, daí Lukács falar de uma infantilidade épica em contraposição à virilidade madura do romance. Desaparecidos os deuses, resta somente ao homem buscar em si as ideias que proporcionarão as relações estruturadoras do Cosmo, mas essas relações nunca poderão deixar de ser formalizações particulares incapazes de transcender a dimensão individual do homem que busca.

O mundo romanesco não é caótico, ele possui sua regularidade, mas as estruturas que a configuram não são mais transcendentes; elas nem asseguram o Ser às coisas nem apontam uma possibilidade disso acontecer na posteridade do dever-ser. É por isso que o romance começa, como Adorno aponta, com "a experiência do mundo desencantado" (2003, p. 55). Lucien Goldmann, na esteira de Lukács e de René Girard, apresenta tais estruturas como mediações degradadas do mundo regido pelo conformismo e pela convenção da ideologia burguesa (GOLDMANN, 1990, p. 09). A impossibilidade de transcendência de tais estruturas também pode ser apontada como a causa da destruição da exemplaridade possuída pelas ações da experiência que constituíam a sabedoria do narrador, daí Benjamin (1994, p. 201) afirmar que o romancista é incapaz de fornecer conselhos, ou que a informação, outra modalidade comunicativa burguesa, também é incapaz de atingir o domínio do suprapessoal onde a alma satisfaz sua necessidade de sentido, pois ela encontra-se amarrada à circunstância e à explicação que a acompanham (cf. BENJAMIN, 1994, p. 203). Em comum, todas essas reflexões possuem a constatação de que o romance nasce a partir da separação entre ideia e coisa, entre o Ser e o ente, entre idealismo e realidade da qual o homem agora vive distanciado em função da própria abstração que sua subjetividade criou para 
tentar abarcar as coisas. Na teoria de Lukács encontramos duas atitudes fundamentais do homem em relação ao mundo: a do sujeito que busca o sentido através da contemplação e a do sujeito que simplesmente age. Somente este segundo caso poderia ser encontrado nas comunidades fechadas, já que a própria imanência de sentido do mundo impossibilitava o surgimento da necessidade de contemplação, entretanto cada ato daquele que agia era prenhe de sentido, pois a alma ainda não conhecia a incongruência entre ela e as coisas (LUKÁCS, 2000, p. 25). Por outro lado, a completude do mundo proporcionada pela formalização subjetiva é sempre imperfeita e ameaçada pela dissonância que não deixa de lembrar ao homem que o mundo carece de sentido imanente. Esta cisão entre mundo e sentido fez os homens se dividirem de diversas maneiras, uma delas é a ocorrida entre aqueles que contemplam a vida buscando um sentido que ela não mais carrega e aqueles que agem inconscientes do vazio de seus atos. Em comum, ambas as modalidades de homens possuem a convivência com essas estruturas convencionais do mundo abandonado pelos deuses: aquele que contempla mergulha em sua subjetividade por perceber a ausência de sentido do mundo; aquele que age percorre este mundo inconsciente do vazio de suas ações, posto que elas se desenvolvem dentro da esfera de um idealismo convencional.

Lucien Goldmann (1990) desenvolve esta reflexão a partir da teoria do fetichismo. Em sua sociologia do romance, essas estruturas ideais são apresentadas como sendo derivadas dos valores do individualismo liberal, responsável pelo esvaziamento da essência das coisas, de sua realidade, identificada aos valores de uso, e o consequente preenchimento pelos valores de troca. Assim, o desenraizamento transcendental das estruturas é explicado por ele através da mediação da realidade através desses valores de troca. A mediação impediria o contato com a realidade, ocasionando a degradação do mundo no artificialismo das convenções burguesas. Assim, ao combinar a Teoria do Romance de Lukács com outras teorias, sobretudo as de Marx e Girard, Goldmann chega a uma definição de romance:

O romance caracteriza-se como a história de uma pesquisa de valores autênticos de um modo degradado, numa sociedade degradada, degradação que, no tocante ao herói, manifesta-se principalmente pela mediatização, pela redução de valores autênticos ao nível implícito e ao seu desaparecimento enquanto se apresentem como realidades manifestas (GOLDMANN, 1990, p. 15). 
Diferentemente de Lukács, que defende que as estruturas transcendentais se perderam completamente e de maneira irreversível com o desaparecimento das antigas comunidades fechadas, Goldmann argumenta que as estruturas autênticas, a realidade e os valores não convencionais, encontram-se presentes no romance, ainda que de maneira implícita. Elas existem na consciência do romancista e se revelam através da ironia. Essa diferença pode ser explicada pela influência das ideias de René Girard em sua teoria. Girard defende que o romancista necessita reencontrar a transcendência do convencionalismo para produzir sua obra. É desnecessário, entretanto, deter-se nessas diferenças, assim como não há como entrarmos aqui na problematização de sua tese da transposição da vida cotidiana para as estruturas literárias, pois basta ao objetivo deste ensaio apontar como alguns dos fundamentos lançados por Lukács são aproveitados pelo marxismo de Goldmann, sobretudo no que diz respeito ao papel do indivíduo problemático no gênero romanesco.

Este mundo degradado - ou, na terminologia de Lukács, dissonante - mundo carente da organicidade épica e tornado um amálgama mediante uma formalização abstrata, implica a separação da comunidade em indivíduos problemáticos. $\mathrm{O}$ abandono das essências e a incapacidade das ideias se ligarem definitivamente à realidade obrigam o indivíduo a responsabilizar-se por sua vida, pela jornada rumo ao autoconhecimento. Daí Lukács definir o romance como a forma da "virilidade madura". Outra forma comum de caracterizar o romance é através da ideia de busca, da imagem da viagem rumo ao sentido de uma individualidade:

O processo segundo o qual foi concebida a forma interna do romance é a peregrinação do indivíduo problemático rumo a si mesmo, o caminho desde o opaco cativeiro na realidade simplesmente existente, em si heterogênea e vazia de sentido para o indivíduo rumo ao autoconhecimento (LUKÁCS, 2000, p. 82).

Esta carência de sentido para sua própria individualidade, derivada dos idealismos opacos nos quais o sujeito encontra-se mergulhado, é o que caracteriza o herói romanesco enquanto um indivíduo problemático. Outra maneira de enxergar isso é notar como ele perdeu a correspondência exata com a medida do mundo. O herói romanesco não somente é um indivíduo deslocado, isolado, mas - e talvez isso seja mais importante que o seu deslocamento - ele é também um indivíduo desmedido. Essa é uma ideia bastante importante para a teoria de Lukács, e talvez seja um dos seus 
aspectos que não foi continuado pelos outros pensadores da forma romanesca. Ela se liga à divisão acima mencionada entre os indivíduos que agem e os indivíduos que contemplam. Essa divisão serve à Lukács para refletir diferentes formas da condição problemática dos heróis romanescos e, a partir delas, desenvolver uma tipologia das formas romanescas. Se o herói se apresenta como um indivíduo caracterizado pela ação, se ele é um ser que age a partir das estruturas opacas do mundo da convenção, seu caráter problemático o torna menor que o mundo; se, por outro lado, ao invés de agir ele se decide pela contemplação de tais estruturas, a desmedida de sua alma o torna maior que o mundo.

Comentadores posteriores que utilizaram a ideia de herói problemático - ou pensadores cujas ideias em algum ponto derivem da ideia de indivíduo problemático lançada por Lukács - não se detêm precisamente sobre os diferentes tipos de caráter problemático do protagonista do romance. Goldmann as menciona, mas suas ideias não se articulam com a tipologia apresentada por Lukács. Benjamin sempre faz referência ao caráter solitário dos heróis romanescos, mas também não chega a pensar as diferentes formas dessa solidão se configurar na forma filosófica do romance.

A categoria de herói problemático é habitualmente lembrada quando se realiza uma leitura do protagonista de São Bernardo. Entretanto não parece ser igualmente comum uma reflexão mais detida sobre as categorias de herói problemático tais como elas foram colocadas por Lukács em A teoria do romance. Torna-se necessário, portanto, que estas leituras sejam avaliadas juntamente com o cotejo da tipologia formulada por Lukács. Esta tarefa será realizada juntamente com uma breve leitura de outros dois romances da literatura brasileira - Dom Casmurro e Triste fim de Policarpo Quaresma. Eles serão considerados, porém, unicamente a fim de servirem de modelos paradigmáticos que contribuam para a análise do livro que de fato se encontra em questão.

\section{O caráter problemático de Paulo Honório}

O primeiro ensaio que associa Paulo Honório à categoria de herói problemático de Lukács é O mundo à revelia (1985), de João Luiz Lafetá. É necessário apontar que o referido texto não pretende ser uma análise exaustiva e cuidadosa de tal questão; ao invés disso, sua preocupação parece ser mais a de captar uma série de elementos 
composicionais de São Bernardo relacionando elementos formais apresentados pela obra com aspectos conteudísticos. Lafetá argumenta que o livro encontra-se dividido em dois ritmos distintos: um mais dinâmico, em que a personagem principal domina o seu universo e imprime-lhe sua cadência; e outro mais lento, correspondente à introspecção em que a personagem mergulha após o suicídio de sua esposa. Essa divisão é apontada corretamente, posto que ela parece ser uma das razões de ser do romance e o ensaio de Lafetá capta esses dois momentos do protagonista-narrador muito bem. A categoria de herói problemático surge quando a análise se detém no segundo momento de desenvolvimento da personagem:

A verdadeira busca começa onde termina a vida de Paulo Honório. A busca verdadeira, entenda-se, a procura dos verdadeiros e autênticos valores que deveriam reger as relações entre os homens. A vida terminou, o romance começa. O romance, segundo Lukács, é a história da busca de valores autênticos por um personagem problemático, dentro de um universo vazio e degradado, no qual desapareceu a imanência do sentido à vida. Ora, só neste instante o herói se torna problemático, o universo surge como vazio e degradado, o sentido da vida desaparece. Antes, Paulo Honório fora um personagem coeso e forte, movendo-se em um mundo de objetivos claros e (ainda que ilusórios) repleto de significado: a propriedade. $\mathrm{O}$ suicídio de Madalena desmascara a falsidade do sentido e problematiza tudo. Agir para quê? - pergunta-se ele. "Nesse movimento e nesse rumo haveria muito choro e muita praga." (LAFETÁ, 1985, p. 210).

O primeiro aspecto que pode ser percebido neste parágrafo é a presença da terminologia de Goldmann mediando a leitura do analista das ideias de Lukács. Ainda que não esteja citado, a definição de romance utilizada, que Lafetá atribui a Lukács, é, entretanto, mais aparentada à apresentada por Lucien Goldmann, o que explica a utilização de termos como "valores autênticos" ou "universo degradado". Noções oriundas do pensamento de Lukács, como "imanência de sentido" e "busca", ou a ideia de que o romance começa quando a vida termina, também aparecem, mas eles são empregados de uma maneira singular.

Apesar da definição de Goldmann derivar da teoria de Lukács, ela é diferente, e suas diferenças devem ser notadas. Ambos falam de uma busca como centro da narrativa romanesca, mas enquanto Lukács fala de uma busca em direção ao autoconhecimento, da alma perseguindo sua própria essência (LUKÁCS, 2000, p. 91), 
Goldmann se refere a uma busca por valores autênticos. A diferença pode até ser tomada como sutil, mas ela não pode deixar de ser considerada significativa. O principal aspecto dela deve-se ao fato de que a busca a que Lukács se refere é destinada ao fracasso porque é impossível, pois as estruturas com as quais a alma se defronta na busca pelas essências não conseguem penetrar na realidade: "Depois da conquista desse autoconhecimento, o ideal encontrado irradia-se como sentido vital na imanência da vida, mas a discrepância entre ser e dever-ser não é superada" (LUKÁCS, 2000, p. 82). Para Lukács, o autoconhecimento não pode ser atingido dentro da esfera do romance, o máximo possível seria um mero vislumbre. Goldmann, por sua vez, ao colocar os valores autênticos como o fim da busca, além de retirar a questão do autoconhecimento como fundamento do romance, sugere que a concretização das relações transcendentais poderia ser encontrada através da superação das estruturas vivenciadas no individualismo liberal. Goldmann pode assim argumentar porque ele acredita que o objeto da busca, os valores autênticos, existe de fato na intencionalidade do autor e encontra-se presente na obra mediante a utilização da ironia, ao passo que Lukács defende que o mundo do romance foi definitivamente abandonado pelos deuses e nada poderá trazer de volta a imanência de sentido às coisas e aos atos. Essa diferença leva Goldmann a construir uma teoria na qual o caráter negativo do romance passa a ser interpretado através das categorias de certo e errado, bem e mal. O mundo degradado do romance parece ser um mundo mau e errado devido às ilusões proporcionadas pelas convenções burguesas, ao passo que em Lukács a negatividade do mundo romanesco situa-se além ou aquém de tais questões (apesar de poder ser relacionado a elas); a referência à negatividade aqui serve para descrever uma situação na qual as coisas não são mais dadas gratuitamente ao homem através de favores divinos, mas antes são conseguidas através da busca pelo amadurecimento da alma. Para Lukács, o indivíduo que sai ao mundo em busca de si deve pagar o preço relacionado à impossibilidade de suas descobertas transcenderem a ausência de sentido encontrada na realidade; já em Goldmann aquele que sai deve tentar conseguir superar a esfera do convencionalismo e atingir o espaço ontológico onde as relações humanas são travadas de maneira adequada.

Feitas estas considerações, é possível perceber que a definição do caráter problemático de Paulo Honório realizada por Lafetá aproxima-se mais do entendimento 
de Goldmann do herói romanesco enquanto indivíduo problemático que da de Lukács, apesar deste ser referido e não aquele. Segundo Lafetá, Paulo Honório adquire elementos problemáticos apenas no final da narrativa, no momento em que ela adquire caráter mais intimista, sua linguagem abandona o estilo seco e aproxima-se mais da “lamentação elegíaca” (LAFETÁ, 1985, p. 210). Antes deste momento, ainda segundo a leitura de Lafetá, Paulo Honório não possuía caráter problemático, pois apresentava um caráter coeso, forte, e movimentava-se segundo objetivos claros. É importante também ressaltar que quando Lafetá refere-se à busca, ele a adjetiva como verdadeira, o que significa que a personagem será problemática somente se sua busca não for a falsa busca. Lukács não menciona uma busca verdadeira, em contraposição a uma busca falsa. Importante ao herói é simplesmente que ele busque, toda busca será, em certo sentido, falsa, pois a transcendência é impossível, e, em certo sentido, verdadeira, pois não há o que ser feito senão partir em busca de um sentido para si. Somente na teoria de Goldmann pode-se falar em uma busca verdadeira (apesar de ele adjetivá-la como degradada), pois sua teoria é construída a partir de valores tomados enquanto verdadeiros, os valores de uso, em oposição aos ilusórios valores burgueses, os valores de troca.

Outro ponto na interpretação de Lafetá diz respeito à questão do sentido da vida: enquanto Paulo Honório possuía um sentido, um objetivo definido, ainda que ilusório, ele não pode ser considerado problemático, isso somente ocorre quando ele passa a questionar seus antigos valores e assume um aspecto mais introspectivo e lamentoso. Este entendimento coloca o caráter problemático da personagem romanesca dentro de uma dicotomia simplista que desconsidera a primeira tipologia do herói problemático, definida por Lukács como idealismo abstrato. Mas isso é necessário à definição de Lafetá porque ela encontra-se condicionada pela teoria de Goldmann. Paulo Honório somente poder ser entendido enquanto um indivíduo problemático porque ele, após o suicídio de Madalena, passou a perceber a falsidade da ideia de propriedade, que até então estruturava seus valores e mediava suas relações com os outros e com o mundo. Ora, se entendermos o herói problemático como aquele que busca os valores autênticos, torna-se necessário que ele esteja consciente dessa busca, de modo que ela não pode começar enquanto o indivíduo continue a agir segundo as referências do individualismo liberal. Segundo a interpretação de Lafetá, somente a consciência da vacuidade das 
referências capitalistas levará a personagem à lamentação e ao intimismo, condições para o aspecto problemático. Lukács, entretanto, não condicionou a existência do herói problemático a uma consciência de si enquanto indivíduo problemático, isso somente poderia ser verificado quando se tem a categoria do romantismo da desilusão, que ocorre quando a alma se sente maior que o mundo, mas a primeira modalidade de indivíduo problemático, a do idealismo abstrato, depende justamente de sua inconsciência em relação ao que é problemático em si, e será justamente por isso que ele possuirá objetivos coesos e claros sem poder se dar conta do quão distante eles se encontram do sentido que a alma busca. A leitura de Lafetá, e todas que se seguiram a partir dela, como veremos, considera possível a condição problemática do herói apenas segundo a categoria do romantismo da desilusão. Isso não seria um problema caso fosse uma conclusão decorrente de um questionamento das categorias de Lukács, mas, ao que parece, o caráter problemático de Paulo Honório é entendido de tal maneira em função de uma leitura de Lukács enviesada pela teoria de Goldmann, o que o leva a uma desconsideração de elementos importantes do indivíduo problemático apresentados em A teoria do romance.

A divisão de Paulo Honório em dois, na qual somente o segundo possui um caráter problemático, foi perpetuada por outras leituras do romance São Bernardo. Benjamin Abdala Júnior fala em uma oposição entre um narrador personagem, ligado ao primeiro momento da narrativa, e um narrador escritor, ligado ao tom mais lamentoso e humanista que o primeiro:

Em São Bernardo, o discurso é articulado a partir da dividida personagem Paulo Honório, que oscila entre uma perspectiva reificadora do narrador-personagem (apreensão capitalista dos bens materiais e da literatura) à do problemático narrador-escritor (apreensão humanista, de caráter socialista, por onde passam mais evidentes as marcas do autor-implícito) (ABDALA, 2007, p. 89).

Apesar de a questão tratada por Abdala ser outra - a convivência de duas inscrições discursivas no romance - deve-se notar que a caracterização da segunda inscrição, a do narrador escritor, é realizada a partir do termo problemático, o que novamente reforça a ideia de que Paulo Honório somente atinge tal condição quando ele se dá conta do caráter ilusório da formalização capitalista do mundo. Viviane Fleury Faria, em sua tese de doutorado, parece corroborar com essa ideia: 
Quando entra em cena o Paulo Honório problemático, a distância [entre ele e o mundo] desaparece, o foco narrativo se introjeta e leva os demais paradigmas literários também a uma introspecção. A linguagem ganha aspectos sombrios, a descrição de paisagens sofre certo embotamento, como também o tempo presente, da enunciação, agora desprovido de marcações, mistura-se ao passado, do enunciado (FARIA, 2006, p. 168).

A leitura dos fragmentos de Lafetá, Abdala e Faria parece atestar certa tradição crítica sobre a personagem Paulo Honório que parece consolidar um determinado entendimento de seu caráter problemático. Segundo tal tradição, possivelmente desencadeada pelo texto de Lafetá, Paulo Honório atinge sua condição problemática apenas quando passa a vivenciar a desilusão decorrente da perda de uma visão de mundo capitalista. Como já apontamos, este entendimento depende do conceito que Goldmann apresenta de herói problemático, pois nela é que encontramos um indivíduo em busca de uma verdade por trás do véu capitalista. Diante de tal concepção, pode-se dizer que o indivíduo não somente é problemático, mas também problematizador, já que seu caráter problemático encontra-se condicionado à sua capacidade de crítica às relações capitalistas. Esta leitura adéqua-se à segunda categoria da tipologia de Lukács, a do idealismo abstrato, mas não considera toda a argumentação contida em A teoria do romance, pois uma interpretação de São Bernardo que busque se orientar por ela concluiria que desde o início Paulo Honório apresenta um caráter problemático. Tornase, portanto, necessário revisitar a tipologia romanesca esboçada por Lukács, os diferentes modos pelos quais o herói romanesco pode ser entendido enquanto um indivíduo problemático, e então tentar uma leitura de Paulo Honório que verifique outra possibilidade de entender seu caráter problemático.

\section{Paulo Honório como idealista}

Segundo Lukács, haveria três formas romanescas e elas sucedem-se umas às outras não somente cronologicamente, mas também conceitualmente (cf. LUKÁCS, 2000, p. 123). Isto significa que os dois principais modos problemáticos do herói romanesco possuem uma sequência lógica e formal, de maneira que em uma esfera teórica eles se completam em uma unidade que se poderia tomar como a estrutura total 
do indivíduo problemático. A primeira forma é a do idealismo abstrato, caracterizado pela presença de um ideal apriorístico que afasta o indivíduo da realidade:

O demonismo do estreitamento da alma é o demonismo do idealismo abstrato. É a mentalidade que tem de tomar o caminho reto e direto para a realização do ideal; que, em deslumbramento demoníaco, esquece toda a distância entre ideal e ideia, entre psique e alma; que, com a crença mais autêntica e inabalável, deduz do dever-ser da ideia sua existência necessária e enxerga a falta de correspondência da realidade a essa exigência a priori como o resultado de um feitiço nela operado por maus demônios, feitiço que pode ser exorcizado e redimido pela descoberta da palavra mágica ou pela batalha intrépida contra os poderes sobrenaturais. (LUKÁCS, 2000, p. 100).

O elemento mais característico do idealismo abstrato é a sua crença inabalável em um ideal; disso decorre a incapacidade de perceber que a ideia não consegue proporcionar um contato direto com a realidade. Todas as vezes em que o herói se depara com alguma situação que poderia revelar o aspecto vazio de suas ideias, a responsabilidade é atribuída a terceiros, nunca ao caráter arbitrário de sua abstração. A sua crença e a sua incapacidade de questionamento o leva a um estado de pura atividade, o que o torna um homem completamente voltado para fora, pois a força de seu idealismo impede a introspecção e o autoquestionamento: “A absoluta ausência de uma problemática internamente vivida transforma a alma em pura atividade. Como ela repousa intocada por todos em sua existência essencial, cada um de seus impulsos tem de ser uma ação voltada para fora" (LUKÁCS, 2000, p. 102).

O exemplo paradigmático escolhido por Lukács é o Dom Quixote. Imerso pelo ideal de cavaleiro andante, o herói mergulha em um estado de pura atividade que lhe rende incapaz de travar um contato a realidade que o cerca. Um exemplo retirado da literatura brasileira capaz de servir de modelo paradigmático - até mesmo por sua semelhança com o herói de Cervantes - é o Policarpo Quaresma. Neste caso a ideia que sustenta a abstração responsável pelo distanciamento da alma em relação à realidade é a ideia de Pátria. Desde o início da narrativa o protagonista é absorvido completamente pelo sentimento patriótico e nele toda a sua individualidade encontra-se consumida: "A razão tinha que ser encontrada numa disposição particular de seu espírito, no forte sentimento que guiava sua vida. Policarpo era patriota. Desde moço, aí pelos vinte anos, o amor da Pátria tomou-o todo inteiro" (BARRETO, 1999, p. 22). Imerso em seu ideal, 
Policarpo se lança em diversos empreendimentos: aprende violão, pesquisa cantigas populares, escreve uma petição para a implementação do Tupi-Guarani como língua oficial, cultiva a terra. Todas essas empresas possuem um único propósito: servir de prova da grandiosidade do Brasil, mas em cada uma delas ele encontra somente o fracasso, pois a ideia que os sustenta não passa de arbitrariedades incapazes de dar conta de qualquer elemento que seja da realidade. A contradição entre ideia e real, entretanto, não é enxergada por Policarpo, os seus fracassos, ao invés de serem atribuídos à ação de feiticeiros, como em Dom Quixote, são atribuídos à falta de patriotismo dos demais brasileiros. Enquanto a narrativa não chegar ao fim, os fracassos serão incapazes de levar seu protagonista à introspecção reflexiva; contraditoriamente, eles o impulsionam ainda mais à atividade. Quanto mais o herói mergulha no ideal que alimenta sua monomania, mais ele se encontra afastado dos homens e da realidade. O caráter problemático do herói aqui se deve justamente à sua coesão e força, aos sentidos claros que oferecem um rumo à sua vida, mas quanto mais mergulhado nesse ideal, mais acentuado torna-se o seu caráter problemático: “O máximo de sentido alcançado em vida torna-se o máximo de ausência de sentido: a sublimidade torna-se loucura, monomania" (LUKÁCS, 2000, p. 103). A narrativa proporcionada pelo idealismo abstrato é a história desses embates entre ideal e real, e o acúmulo de fracassos não será suficiente para revelar ao herói o caráter arbitrário das convenções que regem a sua vida até que a narrativa chegue ao fim. O fim da história é o despertar do protagonista para a ausência de sentido das estruturas até então utilizadas para mediar seu contato com a realidade. A iluminação obtida, entretanto, não serve à superação dessas estruturas, ao invés disso, o que resta é apenas o herói mergulhado na melancolia proporcionada pelo esvaziamento do sentido que até então se julgava poder ser encontrado na vida. Nesse momento, que é o final da narrativa, o herói abandona o estado de pura atividade e dedica-se à contemplação que lhe revela o oco das estruturas até então utilizadas na elaboração de uma formalização do real. É natural que neste momento a linguagem assuma tons mais psicológicos e introspectivos. A crueldade da ausência de sentido do real é tão maior quanto mais o indivíduo julgava poder apreendê-lo pelo ideal, pois o esvaziamento das relações formais implica também um esvaziamento do ego e o reconhecimento de sua pequenez em relação ao mundo. Assim, depois de ser condenado e enquanto espera sua execução, seu triste e irônico fim, Policarpo tem um longo 
momento de contemplação no qual passa em revista toda a sua vida, dessa vez livre das ilusões causadas pelo seu excessivo patriotismo. Cito apenas o parágrafo final dessa reflexão:

\begin{abstract}
Mas, como é que ele tão sereno, tão lúcido, empregara a sua vida, gastara o seu tempo, envelhecera atrás de tal quimera? Como é que não viu nitidamente a realidade, não a pressentiu logo e se deixou enganar por um falaz ídolo, absorver-se nele, dar-lhe em holocausto toda a sua existência? Foi o seu isolamento, o seu esquecimento de si mesmo; e assim é que ia para a cova, sem deixar traço seu, sem um filho, sem um amor, sem um beijo mais quente, sem nenhum mesmo, e sem sequer uma asneira! (BARRETO, 1999, p. 176).
\end{abstract}

É importante notar que a narrativa proporcionada pela categoria do idealismo abstrato possui esse final como característico, pois ela é a história da queda do herói em função de suas próprias crenças. Dom Quixote, passa pelo mesmo momento de contemplação melancólica ao fim de sua vida:

Tenho o juízo já livre e claro, sem as sombras caliginosas da ignorância com que se ofuscou a minha amarga e contínua leitura dos detestáveis livros das cavalarias. Já conheço os seus disparates e os seus embelecos e só me pesa ter chegado tão tarde a este desengano, que não me desse tempo para me emendar, lendo outros que fossem luz da alma (CERVANTES, 2003, p. 675).

Isso não nos deve levar a pensar que somente no final o herói assuma um caráter problemático, o que ocorre é a sua conscientização e o abandono da aventura para passar a viver internamente o seu caráter problemático. A melancolia na qual termina o herói idealista é o início da segunda tipologia romanesca, que, como já mencionado acima, era tida por Lukács como a sequência formal e histórica da primeira. A segunda forma, o romantismo da desilusão, ocorre quando o a priori abstrato da ideia cede lugar à concretude do mundo interno do indivíduo, pois agora é este mundo que serve de $a$ priori fundamental da narrativa, de modo que ela possuirá uma feição psicológica:

O romantismo da desilusão pode ser considerado a antítese do idealismo abstrato. Enquanto naquele o herói era pura atividade, neste temos a pura contemplação; em um tínhamos a falta de uma problemática internamente vivida, agora temos a vida vivida a partir de dentro e o conflito que disso resulta. $\mathrm{O}$ demonismo do idealista é a projeção de estruturas arbitrárias no mundo que são incapazes de corresponder à sua realidade, a do desiludido é justamente a incapacidade de encontrar sentido na realidade 
externa que corresponda à realidade interna, pois a alma passou a enxergar o mundo como regido pelas convenções ilusórias que o idealista tomava por concretas. Daí o caráter passivo e esquivo do herói encontrado nesta categoria de romance, pois nada do que o mundo apresenta é capaz de satisfazer a necessidade de sentido autêntico que a alma anseia.

Para estabelecermos um exemplo paradigmático dessa tipologia escolhemos o romance Dom Casmurro. Nele encontramos a história de um herói que, depois de não ter sido bem sucedido no casamento e viver solitário e amargurado devido ao rumo tomado por sua vida, decide narrar seu passado, sobretudo a sua juventude junto àquela que foi sua primeira e única paixão. Todos os acontecimentos lembrados são narrados apenas em função da pertinência que eles possuem para a explicação da condição atual do narrador, de maneira que sempre o falar sobre os outros se torna um modo de desenhar o mundo interno, objeto único da narrativa. Nas raras vezes em que o protagonista se volta para um objeto cuja pertinência com sua problemática internamente vivida é incapaz de ser estabelecida, o narrador, tão logo percebe tal incapacidade, resigna-se a ressaltar sua ausência de sentido. Assim ele o faz quando menciona os medalhões com figuras históricas que decoram sua casa: "Não alcanço a razão de tais personagens. Quando fomos para a casa de Matacavalos, já ela estava assim decorada" (ASSIS, 1987, p. 7). A preocupação com a decoração, com a reconstrução da casa em que ele viveu em sua infância, deve-se unicamente à tentativa de reestabelecer uma interioridade capaz de um contato com a realidade que ele julga ter existido no passado. Mas a cada tentativa tem-se unicamente a lembrança do vazio da vida presente e da impossibilidade de preenchê-la a partir de elementos retirados da realidade externa:

Encarando a si mesmo como uma lacuna, todo o restante não poderá ter um sentido substantivo. Assim, o mundo para ele será metaforizado como uma ópera cuja autoria estaria dividida entre Deus e o diabo, com a particularidade de que aquele não teria tido interesse na criação e não se preocupou em ouvir os ensaios e realizar as emendas, o que explica os desconcertos, os absurdos e falta de sentido do mundo, ao passo que o diabo teria continuado empenhado em executar com maestria sua orquestração (ASSIS, 1987, p. 20). Sendo o mundo um receptáculo incapaz de receber sentidos autênticos, posto que feito por um demiurgo desleixado, a pura interioridade 
torna-se a única instância capaz de significá-lo, daí a escritura do livro; ela ordenará os fatos de sua vida e estabelecerá o momento em que ela teria desandado; assim como os possíveis culpados por tragédia pessoal.

Este ensaio não se alongará na terceira tipologia apresentada por Lukács, a referente ao chamado romance de aprendizagem, apesar de a literatura brasileira ter um bom exemplo dela no romance de Guimarães Rosa, Grande Sertão: veredas, pois se trata de uma síntese das duas tipologias anteriores e muito pouco sua análise contribuiria ao objetivo proposto inicialmente. Ao invés disso, retornemos ao comentário de Lafetá sobre Paulo Honório, dessa vez tendo em mente as duas primeiras tipologias romanescas encontradas em A teoria do romance. Segundo Lafetá, Paulo Honório possui dois momentos bem característicos: em um que ele encontra-se imerso pela ideia de propriedade, o que desencadeia sua atitude reificadora; e outro em que ele vê o seu antigo mundo fraturado devido à perda dos antigos ideais depois da morte de Madalena. Apenas nesse segundo momento ele assumiria uma configuração problemática, pois somente agora ele não possui mais os objetivos claros que lhe garantiam força e coesão e o universo aparece-lhe como degradado. A partir do que foi exposto acima, não obstante a divisão da personagem parecer acertada, a interpretação de seu caráter problemático nos parece inadequada. Interpretar Paulo Honório como um herói problemático apenas quando a personagem assume uma contemplação melancólica de sua interioridade implica restringir a totalidade do conceito de herói problemático à forma do romantismo da desilusão e desconsiderar a categoria do idealismo abstrato. Considerada esta, serão justamente os motivos elencados para argumentar pelo caráter não-problemático da personagem durante a maior parte de sua história - sua força, coesão e objetivos claros - que levarão à conclusão que desde o início Paulo Honório se apresenta como um herói problemático.

Durante a maior parte de sua história, Paulo Honório encontra-se absorvido pela ideia de propriedade, de acúmulo de bens e de riquezas. Este é o seu único fím e a ideia que o alimenta é responsável pela elaboração de uma rede de referências abstratas que impedem a personagem de perceber a real dimensão das coisas e das pessoas:

Tive abatimentos, desejo de recuar; contornei dificuldades: muitas curvas. Acham que andei mal? A verdade é que nunca soube quais foram os meus atos bons e quais foram os maus. Fiz coisas boas que me trouxeram prejuízo, fiz coisas ruins que me trouxeram lucro. $\mathrm{E}$ como sempre tive a intenção de possuir as terras de S. Bernardo, 
considerei legítimas as ações que me levaram a obtê-las (RAMOS, 1985, p. 39).

Considerado enquanto romance partícipe da tradição do idealismo abstrato, o analista deve reconhecer a inovação formal ocasionada pela narrativa em primeira pessoa, que permite ao herói avaliar seus atos de maneira tão clara e consciente antes do término de sua vida. A avaliação da vida é um dos elementos da estrutura da forma o idealismo abstrato, pois significa o momento de iluminação ocasionado pela jornada rumo ao autoconhecimento que inconscientemente foi empreendida ao longo de todas as suas aventuras, mas ela deve esperar o final do romance e a morte - simbólica ou concreta - de seu protagonista. Ainda assim, esta inovação não desconfigura a forma do idealismo abstrato, na qual temos um herói voltado à pura atividade a partir de referências ilusórias que lhe impedem um contato autêntico com a realidade. É o que se pode perceber que acontece com Paulo Honório a partir da citação acima: o real - as noções de bondade e maldade - encontra-se ofuscado pelas referências derivadas da ideia de propriedade - as ideias de lucro e prejuízo - o que permite ao herói sair pelo mundo travando suas batalhas e contornando as dificuldades inconsciente de que toda a sua empresa não o levará a estabelecer o contato autêntico com o mundo que ele espera. Sempre que algum indício do desconcerto entre ideal e realidade surge, ao invés de atribuir a causa à ação de feiticeiros malignos ou de conterrâneos carentes de patriotismo, Paulo Honório lança mão das acusações de comunismo e de falta de religião, o que lhe permite uma compreensão dos desconcertos da vida sem que seja necessária uma reavaliação de seu idealismo.

\section{Considerações finais}

É certo que as aventuras de Paulo Honório, as ações que ele empreende para adquirir tanto a fazenda como a esposa, são bem menos espetaculosas que as de Dom Quixote ou mesmo que as de Policarpo Quaresma, e por ser menos hiperbólico talvez o caráter idealista do livro seja menos evidente, mas deve ser lembrado que a argumentação de Lukács é desenvolvida ao nível da forma romanesca, não de seu conteúdo. O que importa ser notado é que a personagem volta-se para o mundo externo a partir de uma ideia arbitrária. Se não nos couber julgar seus atos como oriundos de uma loucura, não se pode negar que eles atestam a atitude monomaníaca característica 
do herói idealista. Negar que Paulo Honório apresenta-se enquanto um indivíduo problemático desde o início do romance implicaria aceitar que as ideias que ele utiliza na mediação com a realidade carecem de caráter ilusório e seriam suficientes ao estabelecimento de relações autênticas, mas isso implicaria uma interpretação extremamente grosseira do livro de Graciliano Ramos. Considerar problemático o herói unicamente no final do romance, por outro lado, significaria condicionar o caráter problemático do indivíduo romanesco a uma consciência de si enquanto indivíduo problemático, mas isso, por sua vez, nos leva a desconsiderar o conceito de herói problemático tal qual desenvolvido por Lukács, além do fato de que seria uma solução teórica que também implicaria, por exemplo, considerar que as aventuras de Dom Quixote não estabelecem uma relação problemática com a realidade. Tomando como referência as categorias apresentadas por Lukács, a interpretação adequada do final do romance deve entendê-lo como a conclusão lógica da personagem que despertou de seu mundo ilusório e arbitrário:

Cinquenta anos! Quantas horas inúteis! Consumir-se uma pessoa a vida inteira sem saber para quê! Comer e dormir como um porco! Como um porco! Levantar-se cedo todas as manhãs e sair correndo, procurando comida! E depois guardar comida para os filhos, para os netos, para muitas gerações. Que estupidez! Que porcaria! Não é bom vir o diabo e levar tudo? (RAMOS, 1985, p. 182).

Essa mudança de atitude do herói, que abandona a aventura e começa a autocontemplação, é o final típico dos romances enquadrados a partir da categoria do idealismo abstrato, é por isso que o longo reexame que Paulo Honório faz de sua vida não será parecido com o de Policarpo Quaresma e Dom Quixote por coincidência. Apesar de podermos aproximar São Bernardo a Dom Casmurro em função de alguns elementos conteudísticos semelhantes (a questão do ciúme, o casamento fracassado e etc.), uma análise que considere as formas filosóficas preferirá distanciá-los e aproximar o romance de Graciliano Ramos ao de Lima Barreto. O fundamento de tais comparações pode ser apontado no fato de que a forma de Dom Casmurro depende completamente que a problemática do herói seja vivida internamente ao longo de toda a narrativa, pois o objeto do romance é justamente essa vivência problemática voltada para dentro, ao passo que em São Bernardo, tão logo a problemática de seu herói passa a ser vivida internamente, o romance deve terminar, pois seu objeto era o caminho do herói que 
parte de uma problemática voltada para fora vivida inconscientemente até o momento da queda que lhe proporcionará uma modesta iluminação e a depressão que ela acarreta.

\section{REFERÊNCIAS}

ABDALA JÚNIOR, B. Apropriação da série literária nacional. In: Literatura, história e política: literaturas de língua portuguesa do século XX. São Paulo: Ateliê editorial, 2007.

ADORNO, T. Posição do narrador no romance contemporâneo. In: Notas de Literatura I. Trad. Jorge M. B. de Almeida. São Paulo: Duas Cidades, 2003.

ASSIS, M. Dom Casmurro. São Paulo: Novo Brasil, 1987.

BARRETO, L. Triste fim de Policarpo Quaresma. São Paulo: Ática, 1999.

BAKHTIN, M. Epos e Romance. In: Questões de literatura e de estética. 4 ed. Trad. Aurora Fornoni Bernardini et al.. São Paulo: UNESP, 1998.

BENJAMIN, W. Magia e técnica, arte e política: ensaios sobre literatura e história da cultura. $7^{\mathrm{a}}$ ed. Trad. Sérgio Paulo Rouanet. São Paulo: Brasiliense, 1994.

CERVANTES, M. de. Dom Quixote de La Mancha. Trad. Viscondes de Castilho e Azevedo. São Paulo: Nova Cultural, 2003.

FARIA, V. de. Um fausto cambembe: Paulo Honório. 2006, 206f. Tese (doutorado em literatura). Departamento de teoria literária e literaturas da Universidade de Brasília, Brasília. 2006.

GOLDMANN, L. Introdução aos problemas de uma sociologia do romance. In: A sociologia do romance. Trad. Álvaro Cabral. Rio de Janeiro: Paz e Terra, 1990.

LAFETÁ, J. L. O mundo à revelia. In: RAMOS, Graciliano. São Bernardo. Rio de Janeiro: Record, 1984.

LUKÁCS, G. A teoria do romance: um ensaio histórico-filosófico sobre as formas da grande épica. Trad. Marcos Mariani de Macedo. São Paulo: Duas Cidades, 2000.

RAMOS, G. São Bernardo. Rio de Janeiro: Record, 1984. 